\title{
The Effectiveness of Entrepeneurship Learning In Higher Education
}

\author{
Y Erita ${ }^{1}$, A Ananda ${ }^{2}$ Hamimah $^{3}$ \\ \{yenierita@fip.unp.ac.id\} \\ ${ }^{1,2,3}$ Universitas Negeri Padang, Jl. Prof Dr. Hamka Air Tawar, Padang, Indonesia
}

\begin{abstract}
The process of effective entrepreneurship learning is accompanied by direct practice in the field beside learning the theoretical concept in the classroom. This study aims to determine the effectiveness of applying the entrepreneurship learning in Higher Education. This study was conducted on research and development (R \& D) design of Bold and Gall's model (Borg \& Gall, 1989). This study found that the entrepreneurship learning model is effective based on the indicator of effective model of Joyce and Weil. The effectiveness of applying the entrepreneurship learning model can be seen from the result of pre-test and post-test, and the responses from the lecturer and students which were taken from field observation. This research also showed that the learning process can be done outside the classroom. In conclusion, the development of entrepreneurship learning model can improved the implementation of entrepreneurship learning in university. Thus, the lecturers are suggested to use this learning model to improve the implementation of entrepreneurship learning.
\end{abstract}

Keyword : Entrepreneurship, Education.

\section{Introduction}

The Students entrepreneurial program (PMW) is a program that has a purpose to provide a stock of knowledge, skills and attitude or spirit of entrepreneurship based on science and technology to students in order to change their mindset from job seekers to jobs creator, and become entrepreneurs resilient and successful in facing global competition.

The data from Global Entrepreneurship Index (GEI) in 2015 shows that the position of Indonesia is in 120 of 127 countries and compared to United States which gains the score of GEI 85, Indonesia only has 21 score. Meanwhile, among ASEAN countries, the quality of Indonesia entrepreneurship is far behind Singapore, Malaysia, Thailand and Myanmar which are in rank 8, 10, 52, 68 and 109 respectively.

However, the problem faced by Indonesian nowadays is the number of entrepreneurship is relatively small less than $1 \%$ of Indonesia's population. Then, compared to other ASEAN countries Indonesia is also far behind Singapore (7.2\%) and Malaysia (3\%).

Related to the conditions above, the Indonesian government through the Ministry of National Education considers that it is necessary to encourage the growth of interest in entrepreneurship, especially among the younger generation in college. Therefore, the state and private university should optimized the entrepreneurial learning that equip and and cultivate students' skill and ability in entrepreneurship. 


\section{Method}

This study used the Research and Development design ( $\&$ D), to discover and to test the effectiveness of entrepreneurial learning in Higher Education, so that the new products can be useful for the life of the campus community. Research and development (R \& D) method according to Borg, is a business or activity to develop an effective product to be used and not to test the theory [1]. It is expected to find and test the useful new products for campus community.

The effectiveness of entrepreneurial learning was calculated from the pre-test and post-test data of the improvement of students' knowledge possessed and skills in implementing entrepreneurship learning in the classroom and observing entrepreneurial implementation in the field. This effectiveness test data used a modified percentage formula from as seen below [2].

$$
\mathrm{P}=\frac{\text { total score }}{\text { total ideal score }} \times 100 \%
$$

he effectiveness and the reliability of each instrument were measured using SPSS with the formula [3]:

a) Alpha $(\alpha)$ Cronbach

$$
\alpha \frac{n}{n-1}\left(1-\frac{\sum \sigma i x^{2}}{\sigma T^{2}}\right)
$$

b) Intraclass Correlation Coefficient

$$
\mathrm{ICC}=\frac{\sigma_{\frac{2}{s}}}{\sigma_{\bar{s}}^{2}+\sigma_{0}^{\frac{2}{2}}} \overline{\frac{2}{e}}
$$

To find out the level of students' mastery in theory and practice of entrepreneurship learning, the interpretations are carried out using the following criteria: $0 \%-20 \%$ are very low, $21 \%-40 \%$ are lacking, $40 \%-60 \%$ are moderate, $61 \%-80 \%$ are good, and $81 \%-100 \%$ are very good.

The instrument was used to capture the responses from students, and lecturers. The validity of the instrument was measured by using experts (assessors) judgment and $75 \%$ of the assessors stated that the instrument was valid.

The analysis of the results of the instrument that has been tried out can be obtained by using descriptive analysis [4]. Thus, the data of this study were the result of observations on the feasibility of entrepreneurship learning models, student activities and responses, as well as lecturers' responses.

For the implementation of the entrepreneurial learning model, experts and practitioners provided the value by putting a sign $(\sqrt{ })$ in the column provided based on their experience. Assessment results were presented in a table, and the percentage of observations was determined using the formula:

$$
\mathrm{P}=\left(\frac{M}{M+T}\right) \times 100 \%
$$

$\mathrm{P}=$ Percentage of implementation model.

$\mathrm{M}=$ Frequency of the component of the model based on the value.

$\mathrm{T}=$ Frequency of the component of the model that might not appear

The conclusion was described based on the criteria below:

c) $90 \% \leq$ the implementation model is considered very high.

d) $80 \% \leq$ the implementation model $<90 \%$ is considered high. 
e) $70 \% \leq$ the implementation model $<80 \%$ is considered moderate.

f) $60 \% \leq$ the implementation model $<70 \%$ is considered low.

g) The implementation model $<60 \%$ is considered very low.

\section{Results and discussion}

\subsection{Result}

The effectivenesse test can be seen from a comparison of T-test result and the activity in each meeting. This difference in the effectiveness of the development of entrepreneurial learning model that has been done can be seen from four meetings.

Tabel 1. An Analysis of T-Test

\begin{tabular}{llccccc}
\hline \multicolumn{1}{c}{ Indicator } & \multicolumn{1}{c}{ Mean } & Sig & Alpha & t-test & t-table & Information \\
\hline Business Ethics & $\begin{array}{l}\text { Pre-test }=49.55 \\
\text { Post-test }=87.11\end{array}$ & 0.000 & 0.05 & 16.854 & 2.021 & $\begin{array}{c}\text { Significance } \\
37.55\end{array}$ \\
X Factors & $\begin{array}{l}\text { Pre-test }=47.50 \\
\text { Post-test }=87.95\end{array}$ & 0.000 & 0.05 & 18.985 & 2.021 & $\begin{array}{c}\text { Significance } \\
40.45\end{array}$ \\
$\begin{array}{l}\text { Business } \\
\text { Marketing }\end{array}$ & $\begin{array}{l}\text { Pre-test }=48.00 \\
\text { Post-test }=88.67\end{array}$ & 0.000 & 0.05 & 18.024 & 2.021 & $\begin{array}{c}\text { Significance } \\
40.00\end{array}$ \\
$\begin{array}{l}\text { Financial } \\
\text { Management } \\
\text { and Business } \\
\text { Financing }\end{array}$ & Pre-test $=44.89$ & & & & & \\
\hline
\end{tabular}

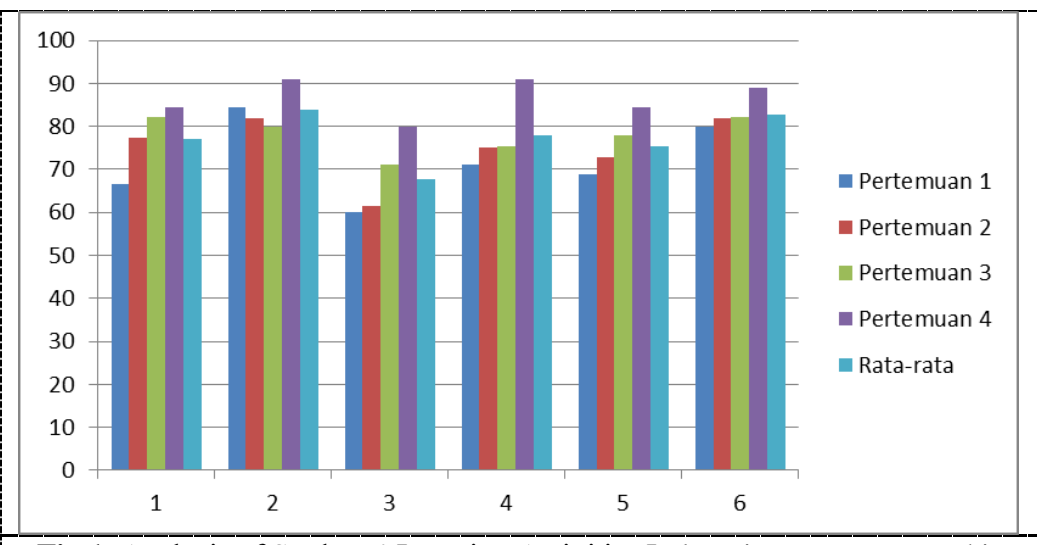

Fig.1. Analysis of Students' Learning Activities In learning Entrepreneurship

The effectiveness aspects of entrepreneurial learning model were obtained by collecting students' response from the questionnaire given after the learning process. There were 45 (forty five) students as respondents and the result of their responses are shown in Table 2 below:

Table 2. Results of Student Response of Entrepreneurship Learning Process

\begin{tabular}{llcl}
\hline No & Aspect Response & $\begin{array}{l}\text { Assessment of Experiment class } \\
\text { Percentage }\end{array}$ & Criteria \\
\hline 1 & Application and Learning & 83,70 & Very Good
\end{tabular}




\begin{tabular}{llll}
\hline & Achievement & & \\
2 & Perception & 79,45 & Good \\
3 & Interest & 79,98 & Good \\
4 & Attitude & 82,57 & Very Good \\
\hline
\end{tabular}

Note: $0 \%-20 \%$, Very Low, $>20 \%-40 \%$,Low, $>40-60 \%$, Average, $>60-80 \%$, Good, $>80-$ $100 \%$, Very Good. After being confirmed by the assessment criteria, the entrepreneurship learning model for the response aspect was considered effective

\subsection{Result of Interview with the Lecturer/Practitioners}

The Interview with the lecturer/practitioner of the faculty was conducted to know their opinion regarding the effectiveness of entrepreneurial learning PKD work book. The interview was done during the experiments performed and in discussing the experiment of each meeting and the work book of PKD entrepreneurial learning. According to the lecturer/practitioner, the instruction of entrepreneurial learning work is very detail that helps them to understand of how to use the book in teaching. They also said that the work book gives step by step guidance of what they need to do in teaching entrepreneurial learning to students. The interview guide can be found in the appendix.

\subsection{Researcher Interviews with Students}

From the interview towards the students book of entrepreneurial learning, it was found that the work book is very clear, detail and understandable. The work book helps the students in understanding the learning material and improve their learning effort. Although it was stated that the work book is interesting but the respondents suggested to adding the video about the successful entrepreneurs to make it more attractive. It can be concluded that work book are practical and effective

\subsection{Discussion}

The product is considered effective if there is consistency between the expectations and, reality and desire. Consistency exists between the intended and experiential curriculum and the intended and the attained curriculum [5]. The effectiveness test is conducted based on the aspects; a) Students learning activities in the learning process, b) the response of students in the learning process and, c) the value of progress of the work in every meeting. From the analysis of the developmental stage of entrepreneurial learning effectiveness test showed that the percentage value assessment of effectiveness aspects was considered effective based on the effective criteria. The results of learning activities of students in entrepreneurial learning in four meetings is $77.91 \%$ the criteria effective and questionnaire responses of students in entrepreneurial learning is $81.51 \%$ with the criteria very good.

\section{Conclusion}

The development of entrepreneurship learning models is feasible to use since it has been tested and declared as valid, practical and effective. The effectiveness test was done from pretest and post-test and the activities in learning with assessment results showed the 
improvement in each meeting with very good criteria. It is important to test the product and improve the product if necessary before it is implemented in the large classes.

\section{Acknowledgment}

Thank you to Universitas Negeri Padang for permitting this research.

\section{References}

[1] Borg and Gall 1989 Educational Research: an Introduction (New York: Longman)

[2] Riduan 2011 Belajar Mudah Penelitian untuk Guru-Karyawan dan Peneliti Pemula (Bandung: Alfabeta)

[3] Eisinga R, Te Grotenhuis M and Pelzer B 2013 International journal of public health 58637

[4] Muliyardi 2006 Pengembangan Model Pembelajaran Matematika Menggunakan Komik di Kelas 1 Sekolah Dasar (Surabaya: PPs UNS)

[5] Plomp T 2010 Educational Design Research: an Introduction (China: East China Normal University) 